\title{
KONTRIBUSI EKSKRESI BASAL PURIN TERHADAP TOTAL EKSKRESI DERIVAT PURIN DALAM URIN KAMBING BLIGON DAN KEJOBONG
}

\section{THE CONTRIBUTION OF BASAL PURINE EXCRETION ON THE TOTAL EXCRETION OF PURINE DERIVATIVES IN THE URINE OF BLIGON AND KEJOBONG GOATS}

\author{
Catur Suci Purwati*, Lies Mira Yusiati, dan Subur Priyono Sasmito Budhi \\ Fakultas Peternakan, Universitas Gadjah Mada, Jl. Fauna No. 3, Bulaksumur, Yogyakarta, 55281
}

\section{INTISARI}

Penelitian ini bertujuan untuk mengetahui perbedaan kontribusi ekskresi basal terhadap total ekskresi derivat purin dalam urin kambing Kejobong dan Bligon. Percobaan ini didesain menggunakan Independent Student t-test untuk membandingkan ekskresi derivat purin keturunan kambing yang berbeda. Pakan yang diberikan adalah jerami kacang tanah (rendeng). Kambing jantan Bligon dan Kejobong masing-masing 6 ekor digunakan dalam penelitian ini. Percobaan ini dibagi menjadi 3 periode yaitu periode adaptasi selama 14 hari, periode koleksi pada saat ternak diberi pakan ad libitum selama 7 hari, dan periode koleksi pada saat ternak dipuasakan. Penentuan kandungan bahan kering (BK), bahan organik (BO), protein kasar (PK), serat kasar (SK), dan ekstrak eter (EE) dilakukan dengan metode analisis proksimat untuk pakan, sisa pakan, dan feses. Pada sampel urin yang diambil saat ternak diberi pakan ad libitum dan dipuasakan dilakukan pengukuran derivat purin yaitu alantoin, asam urat, xantin, dan hipoxantin. Hasil penelitian memperlihatkan konsumsi BK, BO, PK, SK, dan EE menunjukkan perbedaan yang tidak nyata. Nutrien tercerna BK, BO, PK, SK, dan EE juga menunjukkan perbedaan yang tidak nyata. Volume urin kambing Kejobong dan Bligon pada pemberian pakan secara ad libitum menunjukkan perbedaan yang nyata $(\mathrm{P}<0,05)$, dengan rerata kambing Kejobong 953,84 dan Bligon sebesar 762,69 ml/hari. Total ekskresi alantoin dan asam urat kambing Kejobong cenderung lebih tinggi daripada Bligon, sedangkan untuk total ekskresi xantin dan hipoxantin menunjukkan hasil yang berbeda tidak nyata. Total ekskresi derivat purin pada saat pakan ad libitum menunjukkan perbedaan yang nyata $(\mathrm{P}<0,05)$, rerata kambing Kejobong 117,96 $\pm 16,43 \mu \mathrm{mol} / \mathrm{W}^{0,75}$ /hari dan Bligon $72,40 \pm 4,53 \mu \mathrm{mol} / \mathrm{W}^{0,75} /$ hari. Volume urin pada saat dipuasakan menunjukkan perbedaan yang tidak nyata. Rerata volume urin kambing Kejobong 233,04 dan Bligon $201,75 \mathrm{ml} /$ hari. Total ekskresi alantoin kambing Kejobong pada saat dipuasakan cenderung lebih rendah dibanding Bligon, namun untuk total ekskresi asam urat cenderung lebih tinggi kambing Kejobong dibanding Bligon. Total ekskresi xantin dan hipoxantin menunjukkan perbedaan yang tidak nyata. Total ekskresi derivat purin kambing Bligon pada saat dipuasakan lebih tinggi dari kambing Kejobong, dengan rerata kambing Kejobong 18,85 $\pm 4,45$ $\mu \mathrm{mol} / \mathrm{W}^{0,75} /$ hari, dan Bligon sebesar $19,33 \pm 2,28 \mu \mathrm{mol} / \mathrm{W}^{0,75} /$ hari. Derivat purin endogen kambing Kejobong 0,018 $\mu \mathrm{mol} / \mathrm{W}^{0,75}$ sedangkan Bligon $0,019 \mu \mathrm{mol} / \mathrm{W}^{0,75}$. Efisiensi sintesis protein mikrobia kambing Kejobong adalah $0,07 \mathrm{~g} \mathrm{~N}$ mikrobia/hari, sedangkan Bligon 0,04 g N mikrobia/hari dengan BK nutrien tercerna hampir sama. Kontribusi ekskresi basal derivat purin terhadap total ekskresi derivat purin kambing Kejobong 15,98\%, sedangkan Bligon 26,70\%.

(Kata kunci: Ekskresi, Derivat purin, Kambing Bligon, Kejobong)

\section{ABSTRACT}

This study was aimed to examine the contribution of basal purine on the total excretion of purine derivatives in the urine of Kejobong and Bligon goats. The Independent Student t-test was used to compare the excretion of purine derivatives of different goats. The goats were fed peanut hay. This research involved six male Kejobong and six male Bligon goats. The experiment was divided into three periods. The first period was 14 days adaptation. The second period was the collection when the cattles were fed ad libitum for 7 days and the third period was the collection were fasted for 7 days collection. The determination of the content of dry matter (DM), organic matter (OM), crude protein $(C P)$, crude fiber $(C F)$ and ether extract (EE) were performed by the proximate analysis on offered-feed, remaining feed and the goat's faeces. On the collected urine samples of ad libitum-fed goats the measurement of purine derivatives were conducted, i.e. the measurement of allantoin, uric acid, xanthine and hypoxanthine concentrations. The results showed that nutrients (DM, OM, CP, CF and EE) consumpted and digested by both Kejobong and Bligon goats were similar. The mean volume of urine in ad libitum-fed Kejobong and Bligon goats showed significant differences $(P<0.05)$, i.e. $953.84 \mathrm{ml} /$ day and $762.69 \mathrm{ml} /$ day, respectively. The total excretion of allantoin and uric acid of ad libitum-fed Kejobong goats tended to be higher than Bligon goats. Meanwhile, the total excretion of xanthine and hypoxanthine showed no significant differences. The total excretion of purine derivatives of Kejobong goats was higher than that of Bligon goats $(P<0.05)$, with $117.96 \pm 16.43 \mu \mathrm{mol} / W^{0.75}$ of Kejobong goats and $72.40 \pm 4.53 \mu \mathrm{mol} / \mathrm{W}^{0.75}$ of Bligon goats. The total excretion of allantoin of Kejobong goat in fasting period tended to be lower than that of Bligon goat. The volume of urine during fasting showed no significant differences. The mean urine volume of Kejobong goat

\footnotetext{
* Korespondensi (corresponding author):

Telp.+62 8564715 7818, Email: ladivia_88@yahoo.co.id
} 
was 233.04 and Bligon goat was $201.75 \mathrm{ml} /$ day. The total excretion of allantoin of Kejobong goats during fasting tended to be lower than Bligon goats, but the total excretion of uric acid Kejobong goats tend to be higher than Bligon goats $(P<0.05)$, with average $18.85 \pm 4.45 \mu \mathrm{mol} / W^{0.75}$ Kejobong goat, while Bligon goat $19.33 \pm 2.28 \mu \mathrm{mol} / \mathrm{W}^{0.75}$. Endogenous purine derivatives of Kejobong goat were $0.018 \mu \mathrm{mol} / \mathrm{W}^{0.75}$ while those of Bligon were $0.019 \mu \mathrm{mol} / \mathrm{W}^{0.75}$. The efficiency of microbial protein synthesison Kejobong goat was $0.07 \mathrm{~g}$ microbial N/day, while that on Bligon was $0.04 \mathrm{~g}$ microbial N/day with the same digested DM. The contribution of basal excretion of purine derivatives to total excretion of purine derivatives of Kejobong goat was $15.98 \%$, while that of Bligon was $26.70 \%$. The feed efficiency of Kejobong goats was better than Bligon.

(Keywords: Excretion, Purine derivatives, Bligon goat, Kejobong goat)

\section{Pendahuluan}

Pakan merupakan salah satu faktor penentu produktivitas. Pakan yang dikonsumsi oleh ternak mengandung zat gizi seperti karbohidrat dan protein, yang selanjutnya di dalam rumen akan mengalami proses fermentasi oleh mikrobia. Salah satu sumber protein bagi ternak berasal dari protein mikrobia. Evaluasi sintesis protein mikrobia rumen dapat dilakukan dengan cara in vivo umumnya berdasar pada penanda yang dimiliki mikrobia, RNA, DNA, DAPA, maupun penggunaan radioisotop ${ }^{35} \mathrm{~S},{ }^{15} \mathrm{~N}$, atau ${ }^{32} \mathrm{P}$. Seiring berkembangnya ilmu pengetahuan ditemukan metode yang lebih sederhana yaitu dengan metode pengukuran derivat purin.

Derivat purin dalam urin merupakan hasil metabolisme basa purin/asam nukleat dalam tubuh ternak. Secara umum diketahui bahwa metabolisme selalu berjalan secara enzimatik. Mengingat enzim adalah suatu protein yang sintesisnya ditentukan oleh DNA, suatu senyawa organik yang berperan sebagai material genetis maka metabolisme suatu senyawa dapat berbeda di antara spesies yang berbeda. Perbedaan pola metabolisme asam nukleat diduga juga terjadi di antara bangsa ternak (Yusiati, 2002). Derivat purin yang masuk dalam sirkulasi darah selain dari hasil absorbsi juga berasal dari pemecahan asam nukleat jaringan yang disebut dengan derivat purin basal (endogenous). Pada sapi tiga kali lebih besar dibandingkan domba (Chen et al., 1992). Perbedaan tersebut juga ditemukan antar bangsa sapi (Yusiati, 2002).

Berdasarkan uraian di atas, perlu dilakukan penelitian mengenai perbedaan kontribusi ekskresi basal purin terhadap total ekskresi derivat purin dalam urin kambing Kejobong dan Bligon. Selanjutnya data basal derivat purin tersebut akan dapat digunakan untuk rumus sintesis protein mikrobia rumen.

\section{Materi dan Metode}

Penelitian dilaksanakan pada bulan Februari sampai Maret 2012 di Laboratorium Teknologi Makanan Ternak dan Laboratorium Biokimia
Nutrisi, Fakultas Peternakan, Universitas Gadjah Mada.

Penelitian ini menggunakan 2 keturunan kambing Peranakan Ettawa dan Kacang yaitu kambing Kejobong yang berasal dari Purbalingga dan kambing Bligon yang didapatkan dari daerah Gunungkidul, masing-masing 6 ekor, umur antara 8-12 bulan, jenis kelamin jantan, berat badan ratarata $18,75 \pm 2,51 \mathrm{~kg}$.

Pakan yang diberikan adalah jerami kacang tanah (rendeng) yang dicacah terlebih dahulu. Rendeng diperoleh dari daerah Bantul, Yogyakarta. Peralatan yang digunakan adalah timbangan, tempat pakan dan minum yang terbuat dari plastik, gelas ukur, kasa, botol kecil, saringan, kertas lakmus, serta indikator pengukur benda keton. Kandang yang digunakan adalah kadang individu yang dilengkapi dengan alat penampung urin dan feses di bawahnya.

\section{Periode adaptasi}

Ternak ditimbang untuk mengetahui berat badan awal dan berat badan metabolik, kemudian dihitung kebutuhan pakan ternak sesuai dengan berat badan. Pemberian pakan pertama 3\% dari berat badan, kemudian dilihat konsumsinya. Apabila pakan habis maka pada hari berikutnya pakan ditambahkan sampai pemberian ad libitum selama 14 hari sedangkan untuk pemberian air minum ad libitum, tujuannya agar ternak beradaptasi dengan pakan dan lingkungan. Selama waktu tersebut dicatat jumlah konsumsi harian setiap ternak, sehingga diketahui konsumsi saat ternak diberi pakan ad libitum. Pakan dibagi menjadi 2 bagian, yang diberikan 2 kali sehari, pagi hari pukul 08.00 dan sore hari pukul 15.00. Setelah adaptasi ternak dipindahkan pada kandang individual yang di bawahnya telah disediakan alat penampung urin dan feses.

\section{Periode koleksi pada saat ternak diberi pakan ad libitum}

Pada periode koleksi ternak diberikan pakan ad libitum selama 7 hari. Pakan dibagi menjadi 2 bagian, yang diberikan 2 kali sehari, pagi hari pukul 08.00 dan sore hari pukul 15.00. Selama masa 
koleksi dilakukan pengambilan sampel pakan, sisa pakan, feses, dan urin.

Sampel pakan setiap hari diambil $500 \mathrm{~g}$ dan sisa pakan sebanyak $10 \%$ begitu pula sampel feses. Sampel pakan, sisa pakan, dan sampel feses selama koleksi dikomposit dan diikuti dengan pengambilan sub sampel kemudian dipreparasi untuk kemudian dianalisis, guna menentukan kandungan $\mathrm{BK}, \mathrm{BO}$, PK, SK, dan EE yang dilakukan dengan metode analisis proksimat.

Selama periode koleksi urin yang diekskresikan selama 24 jam ditampung dalam ember plastik, yang telah diisi dengan $10 \mathrm{ml} \mathrm{H}_{2} \mathrm{SO}_{4} 10 \%$, kemudian untuk menurunkan $\mathrm{pH}$ sampai kurang dari 3 dilakukan penambahan $\mathrm{H}_{2} \mathrm{SO}_{4}$. Urin yang tertampung diukur volumenya kemudian diambil sampel urin sebanyak kurang lebih $200 \mathrm{ml}$. Sampel urin kemudian dimasukkan ke dalam botol plastik berukuran $50 \mathrm{ml}$ sebanyak 4 buah. Sampel disimpan dalam suhu $-20^{\circ} \mathrm{C}$, sampai waktu analisis. Pengukuran derivat purin yaitu alantoin, asam urat, xantin, dan hipoxantin dalam urin secara spektrofotometris dengan mengadopsi metode Yang dan Conway (Chen et al., 1990).

\section{Periode koleksi pada saat ternak dipuasakan}

Periode ternak sebelum dipuasakan dilakukan penurunan pakan secara bertahap selama 3 hari. Ternak diberikan pakan $90 \%$ pada hari 1, 60\% pada hari 2 , dan $30 \%$ pada hari 3 . Selanjutnya pada hari ke 4 ternak dipuasakan selama 4 hari, dengan pemberian air minum tetap secara ad libitum. Selama periode puasa dilakukan pengambilan sampel urin untuk analisis derivat purin yaitu asam urat, alantoin, xantin, dan hipoxantin dalam urin secara spektrofotometris dengan mengadopsi metode Yang dan Conway (Chen et al., 1990).

\section{Analisis data}

Data hasil penelitian diuji dengan menggunakan Independent Student t-test untuk membandingkan ekskresi derivat purin kedua keturunan kambing yang berbeda.

\section{Hasil dan Pembahasan}

\section{Konsumsi nutrien kambing Kejobong dan Bligon yang diberi pakan tunggal rendeng ad libitum}

Kandungan nutrien jerami kacang tanah (rendeng) yang digunakan dalam penelitian ini adalah BK $88,00 \%$, BO 78,89\%, PK 13,38\%, LK $1,56 \%$, dan SK 25,36\%. Dari hasil penelitian yang dilakukan oleh Prasetyo et al. (2006), komposisi kimia rendeng adalah $\mathrm{BK} 86,00 \%$, BO $89,40 \%$, PK12,60\%, LK 2,30\%, dan SK 25,80\%. Data Tabel 1 menunjukkan besarnya konsumsi nutrien kambing Kejobong dan Bligon yang diberi pakan secara $a d$ libitum.

Konsumsi nutrien BK, BO, PK, SK, dan EE kambing Kejobong dan Bligon menunjukkan perbedaan yang tidak nyata. Konsumsi nutrien tiap ternak dihitung per berat badan, untuk kambing Kejobong rata-rata berat badan $17,17 \pm 2,48 \mathrm{~kg}$ dan Bligon 20,33 $\pm 1,29 \mathrm{~kg}$. Konsumsi BK untuk kambing Kejobong $8,13 \%$ dari berat badan, sedangkan Bligon $6,95 \%$ dari berat badan. Konsumsi BK kambing dengan berat badan $20 \mathrm{~kg}$ untuk kebutuhan pokok dan aktivitas yang rendah adalah 3\% dari berat badan (NRC, 1981). Pada penelitian ini konsumsi BK menunjukkan hasil yang lebih tinggi karena pakan yang diberikan ad libitum, lebih dari cukup untuk mencukupi kebutuhan hidup pokoknya. Menurut Kartadisastra (1997), tinggi rendahnya konsumsi pakan pada ternak ruminansia sangat dipengaruhi oleh faktor eksternal (lingkungan) dan faktor internal (kondisi ternak itu sendiri). Faktor eksternal pada penelitian ini seperti temperatur lingkungan sama, dan faktor internal seperti palatabilitas, konsentrasi nutrisi, dan bentuk pakan semua sama. Parakkasi (1999) menambahkan, banyaknya jumlah pakan yang dikonsumsi oleh seekor ternak merupakan salah satu faktor penting yang secara tidak langsung mempengaruhi produktivitas ternak. Konsumsi pakan dipengaruhi oleh kualitas pakan dan kebutuhan energi ternak yang bersangkutan.

Tabel 1. Konsumsi nutrien pada kambing Kejobong dan Bligon yang diberi pakan tunggal rendeng secara ad libitum (consumpted nutrients on ad libitum-fed Bligon and Kejobong goats)

\begin{tabular}{|c|c|c|}
\hline $\begin{array}{c}\text { Konsumsi nutrien (g/ekor/hari) (nutrient consumption } \\
(\mathrm{g} / \text { head/day }))\end{array}$ & Kejobong & Bligon \\
\hline $\mathrm{BK}(D M)^{\mathrm{ns}}$ & $1.396 \pm 18,16$ & $1.413 \pm 26,63$ \\
\hline $\mathrm{BO}(O M)^{\mathrm{ns}}$ & $1.101 \pm 14,42$ & $1.115 \pm 20,93$ \\
\hline $\mathrm{PK}(C P)^{\mathrm{ns}}$ & $187 \pm 2,48$ & $189 \pm 3,54$ \\
\hline $\mathrm{SK}(C F)^{\mathrm{ns}}$ & $344 \pm 5,74$ & $345 \pm 9,25$ \\
\hline $\mathrm{EE}^{\mathrm{ns}}$ & $22 \pm 0,40$ & $22 \pm 0,48$ \\
\hline
\end{tabular}

BK: bahan kering (DM: dry matter), BO: bahan organik (OM: organic matter), PK: protein kasar (CP: crude protein), SK: serat kasar (CF: crude fibre), EE: ekstrak eter (extract ether).

ns

Berbeda tidak nyata (non significant). 
Nutrien tercerna pada kambing Kejobong dan Bligon yang diberi pakan tunggal rendeng secara ad libitum

Nilai nutrien tercerna pada kambing Kejobong dan Bligon yang diberikan pakan ad libitum berupa rendeng tersaji pada Tabel 2. Nutrien tercerna BK, BO, PK, SK, dan EE antara kambing Kejobong dan Bligon menunjukkan perbedaan yang tidak nyata. Pada penelitian ini pakan yang diberikan memiliki kandungan nutrien yang sama sehingga nutrien pakan yang tercerna hasilnya tidak berbeda nyata. Nilai nutrien bahan pakan yang dapat dimanfaatkan ternak dapat dilihat dari digestible nutrients (nutrien tercerna). Persentase nutrien tercerna diperoleh dari nilai nutrien tercerna (Tabel 2) dibagi dengan konsumsi nutrien (Tabel 1) dikalikan $100 \%$. Nutrien tercerna bahan kering untuk kambing Kejobong 88,11\%, dan Bligon $89,17 \%$ dari konsumsi bahan keringnya. Hal ini berarti kambing Kejobong dan Bligon dapat memanfaatkan nutrien dengan baik, hanya kurang dari $20 \%$ yang tidak dapat dimanfaatkan.

\section{Total ekskresi derivat purin pada kambing Kejobong dan Bligon yang diberi pakan secara ad libitum}

Rata-rata volume urin pada pemberian pakan secara ad libitum pada kambing Kejobong dan Bligon adalah 953,84 dan 762,69 ml/hari. Hasil analisis variansi menunjukkan perbedaan yang nyata. Volume urin untuk kambing Kejobong hampir sama dengan penelitian Natsir (2008) pada domba yang diberi pakan Leucaena ad libitum tanpa suplemen dihasilkan ekskresi urin 937,20 $\mathrm{ml} /$ hari.

Hasil penelitian menunjukkan bahwa total ekskresi alantoin kambing Kejobong cenderung lebih tinggi dibanding kambing Bligon. Penelitian yang dilakukan oleh Fujihara et al. (1999) menunjukkan bahwa hasil ekskresi alantoin pada domba adalah $92,79 \mu \mathrm{mol} / \mathrm{W}^{0,75}$, terlihat hasil yang mendekati hasil alantoin pada penelitian ini. Chen et al. (1990) menyatakan bahwa ekskresi alantoin pada kambing 32-208 $\mu \mathrm{mol} / \mathrm{W}^{0,75} /$ hari. Total ekskresi alantoin pada kambing Kejobong dan Bligon masih masuk pada range tersebut, walaupun kambing Bligon terlihat lebih kecil. Penelitian lain yang dilakukan oleh Natsir (2008) tanpa memperhitungkan kadar xantin dan hipoxantin pada domba yang diberi pakan basal Leucaena tanpa penambahan suplemen, proposi alantoin sebesar $75,69 \%$ dari total derivat purin, sedangkan pada penelitian ini proporsi alantoin pada kambing Kejobong sebesar $76,69 \%$ dari total derivat purin, sedangkan kambing Bligon 75,76\%. Proporsi alantoin merupakan bagian terbesar dari total derivat purin.

Total ekskresi asam urat pada kambing Kejobong cerderung lebih tinggi dari Bligon, walaupun secara statistik tidak berbeda nyata. proporsi asam urat pada penelitian yang dilakukan oleh Natsir (2008) sebesar $24,31 \%$ dari total derivat purin, sedangkan pada penelitian ini proporsi asam urat kambing Kejobong sebesar $22,76 \%$ dari total derivat purin, sedangkan Bligon 23,31\% dari total derivat purin.

Tabel 2. Nutrien tercerna pada kambing Kejobong dan Bligon yang diberi pakan tunggal rendeng ad libitum (digested nutrients on ad libitum-fed Bligon and Kejobong goats)

\begin{tabular}{lcc}
\hline \hline Nutrien tercerna (g/ekor/hari) (digested nutrient (g/head/day)) & Kejobong & Bligon \\
\hline BK $(D M)^{\mathrm{ns}}$ & $1.230 \pm 15,56$ & $1.260 \pm 26,60$ \\
BO $(O M)^{\mathrm{ns}}$ & $787 \pm 8,35$ & $802 \pm 15,58$ \\
PK $(C P)^{\mathrm{ns}}$ & $23 \pm 0,31$ & $23 \pm 0,49$ \\
SK $(C F)^{\mathrm{ns}}$ & $70 \pm 2,91$ & $71 \pm 3,11$ \\
$\mathrm{EE}^{\mathrm{ns}}$ & $3 \pm 0,00$ & $3 \pm 0,00$ \\
\hline
\end{tabular}

BK: bahan kering (DM: dry matter), BO: bahan organik (OM: organic matter), PK: protein kasar (CP: crude protein), SK: serat kasar (CF: crude fibre), EE: ekstrak eter (extract ether).

ns Berbeda tidak nyata (non significant).

Tabel 3. Total ekskresi derivat purin pada kambing Kejobong dan Bligon yang diberi pakan ad libitum (total excretion of purine derivatives of ad libitum-fed Bligon and Kejobong goats)

\begin{tabular}{|c|c|c|}
\hline Derivat purin $\left(\mu \mathrm{mol} / \mathrm{W}^{0,75}\right)\left(\right.$ purine derivatives $\left.\left(\mu \mathrm{mol} / \mathrm{W}^{0.75}\right)\right)$ & Kejobong & Bligon \\
\hline Alantoin (allantoin) ${ }^{\mathrm{ns}}$ & $90,46 \pm 13,08$ & $54,86 \pm 3,35$ \\
\hline Asam urat (uric acid) $)^{\mathrm{ns}}$ & $26,85 \pm 4,24$ & $16,88 \pm 1,84$ \\
\hline Xantin dan hipoxantin (xanthine and hypoxanthine) ${ }^{\mathrm{ns}}$ & $0,64 \pm 0,19$ & $0,67 \pm 0,23$ \\
\hline Total derivat purin (purine derivatives total) & $117,96 \pm 16,43^{\mathrm{a}}$ & $72,40 \pm 4,53^{\mathrm{b}}$ \\
\hline
\end{tabular}


Proporsi xantin dan hipoxantin merupakan proporsi yang paling kecil. Total ekskresi xantin dan hipoxantin untuk kambing Kejobong dan Bligon menunjukkan perbedaan yang tidak nyata. Terlihat pada proporsi xantin dan hipoxantin kambing Kejobong 0,54\% dari total derivat purin, sedangkan Bligon sebesar 0,93\%. Penelitian lain yang dilakukan oleh Orden et al. (2000) pada domba yang diberikan pakan Leucaena dan Gliricidia, proporsi xantin dan hipoxantinnya sebesar $0,016 \%$ terendah dan $0,023 \%$ tertinggi dari total derivat purin. Hasil tersebut jauh berbeda dengan penelitian ini, hal ini disebabkan aktivitas xantin oksidase tiap spesies berbeda dan pakan yang diberikanpun berbeda. Pada penelitian Astuti dan Wina (2002) yang menggunakan kambing Peranakan Ettawa yang diberikan pakan limbah tempe didapatkan hasil ekskresi xantin dan hipoxantin $0,70 \mu \mathrm{mol} / \mathrm{hari}$, hasil total ekskresi tersebut hampir sama dengan penelitian ini. Total ekskresi derivat purin kambing Kejobong lebih tinggi dari kambing Bligon, terlihat pada hasil analisis variansi yang menunjukkan perbedaan yang nyata $(\mathrm{P}<0,05)$.

\section{Total ekskresi derivat purin pada kambing Kejobong dan Bligon yang dipuasakan}

Periode pemuasaan dilakukan selama 4 hari sampai ternak mengeluarkan benda keton yang diukur dengan rapid test. Secara statistik volume urin pada saat dipuasakan menunjukkan perbedaan yang tidak nyata. Rata-rata volume urin untuk kedua bangsa tersebut hampir sama, dengan ratarata kambing Kejobong 233,04 ml/hari dan Bligon $201,75 \mathrm{ml} /$ hari.

Total ekskresi alantoin pada saat ternak dipuasakan menunjukkan hasil yang berbeda tidak nyata, namun dapat dilihat total ekskresi alantoin kambing Bligon cenderung lebih tinggi dari Kejobong. Penelitian Belenguer et al. (2002) menunjukkan proporsi alantoin pada kambing Murciano-Granadina pada saat dipuasakan sebesar $63,70 \%$ dari total derivat purin, sedangkan dalam penelitian ini proporsi alantoin pada kambing Kejobong dan Bligon berturut-turut adalah 54,49 dan $64,77 \%$ dari total derivat purin. Proporsi alantoin kambing Bligon mendekati hasil penelitian Belenguer et al. (2002).

Total ekskresi asam urat kambing Kejobong juga cenderung lebih tinggi dari Bligon, walaupun secara statistik tidak berbeda nyata. Proporsi total ekskresi asam urat saat puasa, pada penelitian Belenguer et al. (2002) 0,091\% dari total derivat purin, sedangkan pada penelitian ini untuk kambing Kejobong yaitu $44,88 \%$ dan kambing Bligon $34,87 \%$ dari total derivat purin. Proporsi total ekskresi asam urat pada penelitian ini terlihat lebih besar.

Total ekskresi xantin dan hipoxantin menunjukkan perbedaan yang tidak nyata. Xantin dan hipoxantin memiliki proporsi yang paling kecil, pada penelitian ini dengan proporsi total xantin dan hipoxantin pada kambing Kejobong dan Bligon masing-masing sebesar 0,32 dan $0,36 \%$ dari total derivat purin. Hasil penelitian Belenguer et al. (2002) menunjukkan proporsi xantin dan hipoxantin sebesar $0,27 \%$ dari total ekskresi, tidak terlalu jauh dibanding penelitian ini.

Total ekskresi derivat purin puasa pada kambing Bligon lebih tinggi dari kambing Kejobong, terlihat pada hasil analisis variansi yang menunjukkan perbedaan nyata $(\mathrm{P}<0,05)$. Perbedaan total ekskresi derivat purin endogen tiap bangsa berbeda, dalam penelitian Andrade-Montemayor et al. (2004) diperoleh hasil ekskresi derivat purin endogen pada kambing Murciano-granadino sebesar $12,39 \mu \mathrm{mol} / \mathrm{W}^{0,75} /$ hari, sedangkan pada penelitian Jetaka et al. (2005) didapatkan hasil ekskresi total derivat purin endogen $202 \pm 12$ $\mu \mathrm{mol} / \mathrm{W}^{0,75} /$ hari. Hasil penelitian ini berbeda dari penelitian-penelitian sebelumnya, perbedaan tersebut kemungkinan karena perbedaan spesies kambing yang digunakan dalam penelitian.

Ekskresi derivat purin pada kambing Bligon dan Kejobong dapat dihitung dengan menggunakan rumus sebagai berikut, untuk kambing Kejobong $\mathrm{Y}=0,84 \mathrm{X}+\left(0,018 \quad \mathrm{~W}^{0,75} \mathrm{e}^{-0,25 \mathrm{X}}\right)$ sedangkan Bligon $\mathrm{Y}=0,84 \mathrm{X}+\left(0,019 \quad \mathrm{~W}^{0,75} \mathrm{e}^{-0,25 \mathrm{X}}\right)$, dengan $\mathrm{X}$ adalah jumlah purin mikrobia yang terabsorbsi ( $\mathrm{mmol} / \mathrm{hari})$, $\mathrm{Y}$ adalah jumlah purin mikrobia yang dikeluarkan (mmol/hari), sedangkan $\mathrm{W}^{0,75}$ adalah berat badan metabolik (kg). Derivat purin endogen untuk kambing Kejobong $0,018 \mathrm{mmol} / \mathrm{W}^{0,75}$, sedangkan Bligon $0,019 \mathrm{mmol} / \mathrm{W}^{0,75}$. Efisiensi sintesis protein mikrobia kambing Kejobong adalah 0,07 g N mikrobia/hari, sedangkan Bligon $0,04 \mathrm{~g} \quad \mathrm{~N}$ mikrobia/hari dengan BK nutrien tercerna yang hampir sama. Hasil penelitian Astuti dan Wina (2002) pada kambing Peranakan Ettawa yang diberi pakan limbah tempe pasokan $\mathrm{N}$ mikrobia sebesar 2,70-4,53 g/hari, dibandingkan dengan kambing Kejobong dan Bligon, sintesis protein mikrobia kambing Peranakan Ettawa lebih tinggi. Kontribusi ekskresi basal derivat purin terhadap total ekskresi derivat purin kambing Kejobong 15,98\%, sedangkan Bligon 26,70\%. Penelitian Nugroho (2011) yang menggunakan kambing Kejobong dan Bligon yang diberi pakan rumput raja dan jerami kacang tanah didapatkan hasil neraca $\mathrm{N}$ untuk

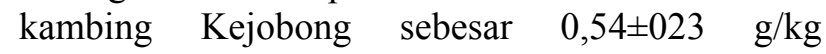
$\mathrm{BBM} /$ hari, sedangkan kambing Bligon sebesar $0,53 \pm 0,10 \mathrm{~g} / \mathrm{kg} \mathrm{BBM} /$ hari. Dengan membandingkan 
Tabel 4. Total ekskresi derivat purin pada kambing Kejobong dan Bligon yang puasa (total excretion of purine derivatives of fasted Kejobong and Bligon goats)

\begin{tabular}{|c|c|c|}
\hline Derivat purin $\left(\mu \mathrm{mol} / \mathrm{W}^{0,75}\right)\left(\right.$ purine derivatives $\left.\left(\mu \mathrm{mol} / \mathrm{W}^{0.75}\right)\right)$ & Kejobong & Bligon \\
\hline Alantoin (allantoin $)^{\mathrm{ns}}$ & $10,46 \pm 2,77$ & $12,52 \pm 1,10$ \\
\hline Asam urat (uric acid) $)^{\mathrm{ns}}$ & $8,56 \pm 2,53$ & $6,74 \pm 1,42$ \\
\hline Xantin dan hipoxantin (xanthine and hypoxanthine) $)^{\mathrm{ns}}$ & $0,06 \pm 0,02$ & $0,07 \pm 0,02$ \\
\hline Total derivat purin (purine derivatives total) & $18,85 \pm 4,45^{\mathrm{a}}$ & $19,33 \pm 2,28^{\mathrm{b}}$ \\
\hline
\end{tabular}

purin terabsorbsi, efisiensi sintesis protein mikrobia, dan neraca nitrogen, menunjukkan bahwa efisiensi penggunaan pakan kambing Kejobong lebih baik dibandingkan Bligon.

\section{Kesimpulan}

Kesimpulan dalam penelitian ini adalah bahwa efisiensi penggunaan pakan kambing Kejobong lebih baik dibandingkan Bligon.

\section{Daftar Pustaka}

Andrade-Montemayor, H. F. Hernández, J. Madrid and M. D. Megías. 2004. Comparison of different models to estimate purine bases absorbed in goats. S. Afr. J. Anim. Sci. 34 (Supplement 1): 28-30.

Astuti, D. A. dan E. Wina. 2002. Neraca protein dan ekskresi derivat purin di urin pada kambing Peranakan Etawah laktasi yang diberi pakan limbah tempe. Jurnal Ilmu Ternak Veteriner 7: 162-165.

Belenguer, A., D. Yanez, J. Balcells, N. H. Ozdemir Baber and M. G. Ronquillo. 2002. Urinary excretion of purine derivatives and prediction of rummicrobial out flowin goats. Lives. Prod. Sci. 77: 127-135.

Chen, X. B., E. R. Orskov and F. D. DeB. Hovell. 1990. Excreation of purine derivatives by ruminant: endogenous excreation, differences beetween catle and sheep. Br. J. Nutr. 63: 121-129.

Chen, X. B., G. Grubic, E. R. Orskov and P. Osuji. 1992. Effect of feeding frequency on diurnal variation in plasma and urinary purine derivatives in steers. J. Anim. Prod. 55: 185191.

Fujihara, T. M. Iwakuni and K. Miyata. 1999. The effect of rumen protozoa on plasma allantoin level and uninary purin derivatives in sheep. S. Afr. J. Anim. Sci. 29: 137-138.
Jetaka, T., N. Abdullah, J. B. Liang, S. Jalaludin and Y. W. Ho. 2005. Purine derivatives excretion and estimation of microbial nitrogen flowed from the rumen of sheep and goats. Thesis. Chulalongkorn University. Chulalongkorn.

Kartadisastra, H. R. 1997. Penyediaan dan Pengelolaan Pakan Ternak Ruminansia (Sapi, Kerbau, Domba, dan Kambing). Kanisius. Yogyakarta.

Natsir, A. 2008. Suplai protein mikrobia rumen yang diestimasi berdasarkan ekskresi turunan purin pada domba yang diberi bijian faba (Vicia faba) sebagai suplemen dengan frekuensi pemberian yang berbeda. Jurnal Ilmu Ternak Veteriner 13: 103-108.

NRC. 1981. Nutrient Requirement of Goat. National Academy of Science. Washington DC.

Nugroho, R. A. 2011. Neraca nitrogen pada kambing Bligon dan Kejobong jantan yang diberi pakan rumput raja dan jerami kacang tanah. Skripsi S1. Fakultas Peternakan Universitas Gadjah Mada.

Orden, E. A., K. Yamaki, Ma. E. M. Orden, S. A. Abdulrazak, T. Ichinohe and T. Fujihara. 2000. Effect of leucaena and gliricidia supplementation on $\mathrm{N}$ balance and urinary. Asian-Aus. J. Anim. Sci. 13 (Supplement B): 27-30.

Parakkasi, A. 1999. Ilmu Nutrisi dan Makanan Ternak Ruminan. Penerbit Universitas Indonesia. Jakarta.

Prasetyo, A., T. Herawati, dan Muryanto. 2006. Produksi dan kualitas limbah pertanian sebagai pakan substitusi ternak ruminansia kecil di Kabupaten Brebes. Seminar Nasional Teknologi Peternakan dan Veteriner. Balai Pengkajian Teknologi Pertanian Jawa Tengah, Ungaran.

Yusiati, L. M. 2002. Pengembangan metode sintesis protein mikrobia rumen mengunakan ekskresi derivat purin dalam urin berbagai ternak ruminansia Indonesia. Disertasi. Fakultas Peternakan Universitas Gadjah Mada. Yogyakarta. 